\title{
Raphia-Microorganism Composite Biosorbent for Lead Ion Removal from Aqueous Solutions
}

\author{
Paweł Staroń * (D) and Jarosław Chwastowski $\mathbb{D}$ \\ Department of Engineering and Chemical Technology, Cracow University of Technology, 24 Warszawska Str., \\ 31-155 Cracow, Poland; jaroslaw.chwastowski@pk.edu.pl \\ * Correspondence: pawel.staron@pk.edu.pl; Tel.: +48-12-628-20-92; Fax: +48-12-628-20-36
}

Citation: Staroń, P.; Chwastowski, J. Raphia-Microorganism Composite Biosorbent for Lead Ion Removal from Aqueous Solutions. Materials 2021, 14, 7482. https://doi.org/ $10.3390 /$ ma14237482

Academic Editor: Andrea Petrella

Received: 10 November 2021

Accepted: 2 December 2021

Published: 6 December 2021

Publisher's Note: MDPI stays neutral with regard to jurisdictional claims in published maps and institutional affiliations.

Copyright: (c) 2021 by the authors. Licensee MDPI, Basel, Switzerland. This article is an open access article distributed under the terms and conditions of the Creative Commons Attribution (CC BY) license (https:// creativecommons.org/licenses/by/ $4.0 /)$.

\begin{abstract}
This study investigated the possibility of obtaining a raphia-microorganism composite for removing lead ions from aqueous solutions using immobilized yeast cells Saccharomyces cerevisiae on Raphia farinifera fibers. The obtained biocomposite was characterized using scanning electron microscopy and Fourier transform infrared spectroscopy. Studies were conducted to determine the influence of contact time, initial concentration of $\mathrm{Pb}(\mathrm{II})$, and $\mathrm{pH}$ allowed for the selection of nonlinear equilibrium and kinetic models. The results showed that the biocomposite had a better $\mathrm{Pb}$ (II) removal capacity in comparison to the raphia fibers alone, and its maximum $\mathrm{Pb}$ (II) adsorption capacity was $94.8 \mathrm{mg} / \mathrm{g}$. The model that best describes $\mathrm{Pb}(\mathrm{II})$ sorption was the Temkin isotherm model, while kinetic studies confirmed the chemical nature of the sorption process following the Elovich model. The obtained research results provide new information on the full use of the adsorption function of biomass and the ubiquitous microbial resources and their use in the remediation of aqueous environments contaminated with heavy metals.
\end{abstract}

Keywords: Saccharomyces cerevisiae; immobilization; adsorption; biosorption; equilibrium; kinetic; yeast

\section{Introduction}

In this era of strong industrial development and increased human activity, water pollution has become a major global problem. In addition, water is an essential element of life on earth, and its storage is decreasing year by year [1,2]. One of the main water pollutants is heavy metals, which have a negative impact on the environment. This is due to their toxic properties in relation to living organisms, and additionally, they are not biodegradable, which causes several environmental problems [3].

Primary pollutants come from burning fossil fuels, fertilizers, pesticides, municipal waste, mining and smelting of ferrous ores, industrial waste, oil spills, nuclear waste spills $[4,5]$. Heavy metals such as lead, nickel, and cadmium have become ecotoxicological hazards of primary importance due to their tendency to accumulate in vital organs of humans and animals (e.g., liver, kidney, brain).

Commonly used processes for removing heavy metal ions from wastewater include chemical precipitation and filtration, chemical oxidation or reduction, electrochemical treatment, reverse osmosis, ion exchange and evaporation [6]. However, these methods are not ideal due to the need for complex instruments and space-consuming equipment, and they generate high maintenance costs, which affect the economics of the process [7]. From an economic perspective, a more promising approach is to use adsorption or photocatalysis processes to remove heavy metals from water and wastewater [8,9]. Currently, widely used adsorbents in the removal of pollutants from water and wastewater include activated carbon, zeolites and various types of clays and aluminophosphates and photocatalysts such as titanium dioxide and metal sulfides. The adsorbents and photocatalysts used are unfortunately not without disadvantages. Among the main disadvantages of the adsorbents mentioned are small surface area and lack of selectivity, while in the case of photocatalysts, it is the low efficiency of sunlight and poor quantum yield of photocurrent [10]. Therefore, 
there is still a great need to develop new and better adsorbents and/or photocatalysts for water and wastewater treatment. Research in recent years has indicated that biosorption is one of the most promising technologies for removing heavy metal ions from water and wastewater. Various types of bio-based materials are widely used, including wastes from households or other industries, including agriculture. Food crops are grown worldwide (e.g., sugarcane, rice, corn, wheat, etc.), and parts other than fruits, grains, juices, etc., are available for biosorption experiments [11]. In addition to the use of dead biomass as heavy metal sorbents (e.g., coconut fiber, peat, wool, sawdust, straw), there are many literature reports on the use of microorganisms (live biomass) that can remove and/or accumulate large amounts of heavy metals [12]. Among these microorganisms, bacteria, fungi, and algae are the most widely used. Several bacterial-based heavy metal remediation methods have been investigated, including Escherichia, Pseudomonas, Bacillus and Micrococcus, fungi, e.g., Aspergillus niger, Aspergillus fumigatus, Termitomyces clypeatus, Saccharomyces cerevisiae, algae, e.g., Fucus vesiculosus, Cladophora fascicularis, Cladophora fascicularis, Cystoseira crinitophylla, Saccharina japonica, and Sargassum fusiforme [13].

The use of microorganisms to remove heavy metals from water and wastewater has advantages but also disadvantages. The main disadvantages include mechanical instability and the difficult separation of biomass after the removal process. To eliminate these disadvantages, various methods are used, including the method of immobilization of microorganisms on the carrier. This allows for increased productivity, improved mechanical strength, and increased chemical resistance. Different types of immobilization have been defined, including by encapsulation or trapping, among others [14]. Encapsulation is associated with the use of semi-permeable membranes, while trapping involves the immobilization of cells in a gel matrix, typically having a bead shape. There are several matrices used to immobilize a given biosorbent containing microbial cells, which include calcium alginate, silica, or polymers such as polyurethanes and polyacrylamide. A particularly important aspect is the use of a properly selected matrix, as it determines the chemical resistance and mechanical strength of the biosorbent. The matrix should be, above all, inexpensive and feasible to produce [15]. The higher biodegradation efficiency observed after the use of immobilized microorganisms in comparison to free ones has led to an increased interest in their application in bioremediation processes [16]. To improve the properties of the obtained composites, a carrier may be used on which microorganisms will be immobilized. The carriers are classified as organic and inorganic or natural or synthetic. Examples of the use of biocomposites to remove contaminants from water and wastewater are: yeast cells immobilized on coconut fiber for lead removal [17], biocomposite materials for $\mathrm{Cr}(\mathrm{VI})$ removal in water by immobilization of a previously isolated Morganella morganii strain [18], removal of chromium ions by agar immobilized cells of the cyanobacterium Anacystis nidulans [19], nanocellulose-based biocomposite coupled with Arthrobacter globiformis as a herbicide degrader for the rapid elimination of diuron [20], biocomposite of Fe-sludge biochar and Bacillus sp for decolorization of Methylene blue dye [21]

The aim of this study was to obtain a composite material constructed from a carrier of natural origin and yeast as a biosorbent for lead ion removal. Raphia (Raphia farinifera) fibers, whose main components are cellulose, hemicellulose, and lignin, was used as the carrier. Raphia fibers have been successfully used as a biosorbent to remove ammonia and methylene blue, confirming its ability to remove pollutants from the aquatic environment $[22,23]$. The biomass used was the yeast Saccharomyces cerevisiae, which is one of the most common microorganisms available in large quantities as a by-product of fermentation processes or the pharmaceutical industry. Saccharomyces cerevisiae has been used by several researchers as a biosorbent to remove or accumulate heavy metals such as copper, cadmium, lead and mercury from wastewater [6]. Sodium alginate immobilization was used as the immobilization method for microorganisms and calcium chloride, which has high biocompatibility, non-toxicity, and simple gelation properties, was used as the crosslinking agent (Zhao et al. 2019). Lead ion removal studies were conducted in batchtype periodic systems. The results obtained determined the maximum sorption capacity 
of the Raphia-Saccharomyces cerevisiae (RA-SC) composite for lead ions and compared them with raphia fibers. Using nonlinear equilibrium and kinetic models, the mechanism of the sorption process was determined.

\section{Materials and Methods}

\subsection{Materials and Chemicals}

The yeast Saccharomyces cerevisiae (SC) (purchased from the National Collection of Yeast Cultures, Norwich, UK), sieved under sterile conditions into pre-sterilized $250 \mathrm{~cm}^{3}$ conical flasks containing YEPD (Yeast Extract Peptone Dextrose Agar) medium, was used to prepare the composite sorbent. The culture was conducted using a laboratory shaker at $25{ }^{\circ} \mathrm{C}$ for $72 \mathrm{~h}$. After this time, the medium in the flask became milky and a precipitate formed at the bottom indicating significant growth of Saccharomyces cerevisiae in the flask. In this study, an inoculum containing S. cerevisiae in a population of approximately $1.5 \times 10^{10} \mathrm{CFU} / \mathrm{cm}^{3}$ was used. The yeast inoculum $\left(80 \mathrm{~cm}^{3}\right)$ was centrifuged for $15 \mathrm{~min}$ at 10,000 RPM using an MPW-260R centrifuge (MPW Med. Instruments, Warsaw, Poland).

Natural raphia (RA) purchased from a commercial store had a fiber width of $5 \mathrm{~mm}$ and a total length of 1-1.2 m. Prior to testing, the material was cleaned of impurities by washing it in deionized water for $30 \mathrm{~min}$ and then rinsing it 3 times with deionized water. The cleaned and $70{ }^{\circ} \mathrm{C}$ dried raphia was ground using a RETSCH${ }^{\circledR}$ MM400 Mixing Mill (Retsch GmbH, Haan, Germany) (vibration frequency: $30 \mathrm{~Hz}$, grinding time: $5 \mathrm{~min}$ ) and then passed through a sieve (Mesh 42). The material thus prepared was designated as RA and used in sorption studies.

Reagents used in the research: YEPD Agar, sodium alginate, calcium chloride, potassium dichromate (VI), lead (II) chloride, cobalt (II) chloride hexahydrate, zinc (II) nitrate hexahydrate, nitric acid (V), sodium hydroxide were characterized by high purity and were from Sigma-Aldrich. All solutions were prepared with deionized water.

\subsection{Preparation of $R A-S C$}

To obtain the RA-CS composite, $2 \mathrm{~g}$ of sodium alginate were added to $98 \mathrm{~cm}^{3}$ of deionized water and heated in a water bath to $90{ }^{\circ} \mathrm{C}$. Then, the mixture was stirred for $2 \mathrm{~h}$ to completely dissolve it. After a homogeneous mixture was obtained (no lumps), $1.0 \mathrm{~g}$ of raphia was added and stirring was continued until a homogeneous mixture was obtained. The raphia concentration in sodium alginate was $10 \mathrm{~g} / \mathrm{dm}^{3}$. The use of raphia improved the mechanical properties and stability of the resulting composite, and as a material of biological origin, it complies with the principles of green chemistry and sustainable development. Then yeast (obtained by centrifugation of $80 \mathrm{~cm}^{3}$ inoculum) was added. The whole content was stirred at a temperature of $30^{\circ} \mathrm{C}$ for $1 \mathrm{~h}$. The mixture prepared in this way was added dropwise with the use of an injector to a solution of calcium (II) chloride with a concentration of $2 \%$. The resulting beads were left in the solution for $10 \mathrm{~min}$. After this time, the resulting RA-SC composite was washed several times with deionized water, and then dried by lyophilization. The dried RA-SC composite was stored at $4{ }^{\circ} \mathrm{C}$ for further experiments.

\subsection{Characterization}

The surface morphology of RA and RA-SC before and after the lead ion removal process was observed using a scanning electron microscope Hitachi TM-3000 (Hitachi High-Technologies Corporation, Tokyo, Japan) equipped with an X-ray microanalyzer EDX Bruker Quantax 70 (Bruker, Berlin, Germany), and EDX spectroscopy was used to detect the elements present, including $\mathrm{Pb}$ present before and after sorption. FTIR spectroscopy was performed to confirm the presence of functional groups on the SC, RA and RA-SC surfaces before and after the sorption process in the wavenumber range $400-4000 \mathrm{~cm}^{-1}$ Thermo Scientific-Nicolet iS5 with the ATR iD7 attachment (Thermo Fisher Scientific, Dublin, Ireland). A specific surface area test was carried out using an ASAP 2010 deaerator 
station. Before measurement, samples were dried in a helium atmosphere at $110^{\circ} \mathrm{C}$ for $8 \mathrm{~h}$, then under vacuum at $100{ }^{\circ} \mathrm{C}$ and 0.001 Tor for $8 \mathrm{~h}$.

\subsection{Sorption Process}

\subsubsection{Choosing the Appropriate Metal Ions}

All heavy metals sorption processes were carried out in batch-type periodic systems. Sorption experiments were carried out in $60 \mathrm{~cm}^{3}$ closed PP containers. The assumption of the selection of heavy metal for the research was to determine the element with the highest affinity for raw RA and RA-SC, which allowed to compare the removal ability of this element by RA and the RA-SC composite obtained based on RA. Pb(II), Co(II), $\mathrm{Cr}(\mathrm{VI})$, $\mathrm{Zn}$ (II) ions were selected for the research and model solutions of these ions were prepared at a concentration of $500 \mathrm{mg} / \mathrm{dm}^{3}$.

The sorption process was carried out, $0.1 \mathrm{~g}$ of RA/RA-SC was weighed into the containers, then $20 \mathrm{~cm}^{3}$ of the model solution of individual ions were added and mixed at a constant speed at $25^{\circ} \mathrm{C}$ for $3 \mathrm{~h}$. After the process was completed, the mixture was separated by filtration. The filtrate was analyzed on an acetylene air-flame atomic absorption spectrometer (F-AAS). The amount of adsorbed metals on the tested adsorbent was calculated from Equation (1) (Table 1).

Table 1. The equation used in the presented study.

\begin{tabular}{cccc}
\hline Isotherm Models & Equation & Reference & No. Equation \\
\hline Sorption capacity & $\mathrm{q}_{\mathrm{e}}=\frac{\left(\mathrm{C}_{0}-\mathrm{C}_{\mathrm{e}}\right) \cdot \mathrm{v}}{\mathrm{m}}$ & [24] & [25] \\
\hline The determination coefficient & $\mathrm{R}^{2}=1-\frac{\sum_{1}^{\mathrm{n}}\left(\mathrm{q}_{\exp }-\mathrm{q}_{\mathrm{pred}}\right)^{2}}{\sum_{1}^{\mathrm{n}}\left(\mathrm{q}_{\exp }-\overline{\mathrm{q}_{\exp }}\right)^{2}}$ & & (1) \\
\hline The average relative error & $\mathrm{ARE}=\frac{100}{\mathrm{n}} \sum_{1}^{\mathrm{n}} \frac{\left|\mathrm{q}_{\exp }-\mathrm{q}_{\mathrm{pred}}\right|}{\mathrm{q}_{\exp }}$ & [26] & (3) \\
\hline
\end{tabular}

On the basis of the obtained results, it was found that the lead ions showed the highest affinity for RA and RA-SC. The sorption capacity for other metals is much lower and is in the following series: $\mathrm{Co}^{2+}<\mathrm{Zn}^{2+}<\mathrm{Cr}^{6+}<\mathrm{Pb}^{2+}\left(\mathrm{Pb}^{2+}: \mathrm{RA}-16.51 \mathrm{mg} / \mathrm{g}\right.$, $\mathrm{RA}-\mathrm{SC}-94.66 \mathrm{mg} / \mathrm{g} ; \mathrm{Cr}^{6+}: \mathrm{RA}-6.16 \mathrm{mg} / \mathrm{g}, \mathrm{RA}-\mathrm{SC}-63.25 \mathrm{mg} / \mathrm{g}, \mathrm{Zn}^{2+}: \mathrm{RA}-0.60 \mathrm{mg} / \mathrm{g}$, $\left.\mathrm{RA}-\mathrm{SC}-12.83 \mathrm{mg} / \mathrm{g}, \mathrm{Co}^{2+}: \mathrm{RA}-0.00 \mathrm{mg} / \mathrm{g}, \mathrm{RA}-\mathrm{SC}-5.42 \mathrm{mg} / \mathrm{g}\right)$. Subsequently, the research focused on lead ions.

\subsubsection{Specific Sorption Studies}

In sorption studies, the influence of variables including time, initial concentration of $\mathrm{Pb}$ (II) and $\mathrm{pH}$ value was checked. $0.1 \mathrm{M} \mathrm{HNO}_{3}$ and $0.1 \mathrm{M} \mathrm{NaOH}$ were used to achieve the intended $\mathrm{pH}$ values. The $\mathrm{pH}$ values were equal to $3,4,5$ and 6 respectively. $\mathrm{pH}$ values below 3 were not used due to the excessive protein denaturing properties in the microbial cells [27]. The research on the effect of $\mathrm{pH}$ on the value of sorption capacity showed that with the increase of $\mathrm{pH}$ from 3.0 to 5.0, the sorption capacity increased, while above 5 it began to decline $(\mathrm{pH}=3$ : RA-5.21 $\mathrm{mg} / \mathrm{g}, \mathrm{RA}-\mathrm{SC}-61.08 \mathrm{mg} / \mathrm{g} ; \mathrm{pH}=4$ : $\mathrm{RA}-12.32 \mathrm{mg} / \mathrm{g}, \mathrm{RA}-\mathrm{SC}-76.42 \mathrm{mg} / \mathrm{g}, \mathrm{pH}=5: \mathrm{RA}-16.51 \mathrm{mg} / \mathrm{g}, \mathrm{RA}-\mathrm{SC}-94.66 \mathrm{mg} / \mathrm{g}$, $\mathrm{pH}=6: \mathrm{RA}-13.91 \mathrm{mg} / \mathrm{g}, \mathrm{RA}-\mathrm{SC}-73.12 \mathrm{mg} / \mathrm{g})$. The obtained results were consistent with the research conducted by [28], which confirms that $\mathrm{H}^{+}$ions compete with metal ions at low $\mathrm{pH}$, and the metal ion binding sites are only available in the deprotonated state. Therefore, as the $\mathrm{pH}$ increases, the density of the positive charge on the surface of the material decreases, so that the protonation effect becomes smaller, which results in greater availability of metal-binding sites [29]. The lead ion sorption process was carried out at the $\mathrm{pH}$ corresponding to the highest $\mathrm{Pb}$ (II) sorption, i.e., $\mathrm{pH}=5$ at $25^{\circ} \mathrm{C}$ using a laboratory shaker with $150 \mathrm{rpm}$ for various concentrations of $\mathrm{Pb}$ (II) - 100, 200, 300, 400 and $500 \mathrm{mg} / \mathrm{dm}^{3}$ for $0.5,1,3,5,8,15$ and $30 \mathrm{~min}$. $0.1 \mathrm{~g}$ of RA or RA-SC was weighed into PP containers, to which $20 \mathrm{~cm}^{3}$ of the solution with a given starting concentration of $\mathrm{Pb}$ (II) 
was added each time. After the process, the sample was filtered using a Buchner funnel and a hard filter. The obtained filtrates were tested for the content of $\mathrm{Pb}$ ions with the use of an atomic absorption spectrometer in an acetylene-air flame (F-AAS). All experiments were repeated 3 times and the results were averaged.

\subsection{Statistical Analysis of the Fitted Models}

The estimation of parameters in all models (equilibrium and kinetic) was made using the nonlinear regression method. The determination coefficient $\left(R^{2}\right)$ and the average relative error (ARE) were used to compare the quality of the results calculated from Equations (2) and (3) in Table 1 were used.

\subsection{Equilibrium Studies}

After equilibrium was reached at a constant temperature, the relationship between the amount of sorbate adsorbed by the sorbent and the concentration of sorbate remaining in the solution after reaching equilibrium was described by adsorption isotherms. The parameters of the models obtained in this way provide a lot of useful information regarding the properties of the sorbent surface, sorption mechanisms and mutual interactions between the sorbent and the sorbate [30]. Many models describe the adsorption equilibrium; however, the main ones used are the Langmuir and Freundlich models, while the literature on the subject also includes the Temkin and Dubinin-Radushkevich (D-R) models. Table 2 presents the equations of the used equilibrium models.

Table 2. Nonlinear equations of isotherm models.

\begin{tabular}{|c|c|c|c|}
\hline Isotherm Models & Equation & Reference & No. Equation \\
\hline Langmuir & $\mathrm{q}_{\mathrm{e}}=\frac{\mathrm{q}_{\mathrm{m}} \mathrm{K}_{\mathrm{L}} \mathrm{C}_{\mathrm{e}}}{1+\mathrm{K}_{\mathrm{L}} \mathrm{C}_{\mathrm{e}}}$ & [31] & (4) \\
\hline Freundlich & $\mathrm{q}_{\mathrm{e}}=\mathrm{K}_{\mathrm{F}} \mathrm{C}_{\mathrm{e}}^{\frac{1}{\mathrm{n}}}$ & [32] & (5) \\
\hline Temkin & $\mathrm{q}_{\mathrm{e}}=\mathrm{Bln}_{\mathrm{T}} \mathrm{C}_{\mathrm{e}}$ & [33] & (6) \\
\hline Dubinin-Radushkevich & $\begin{array}{c}\mathrm{q}_{\mathrm{e}}=\mathrm{q}_{\mathrm{d}} \exp \left(-\mathrm{K}_{\mathrm{ad}} \varepsilon^{2}\right) \\
\varepsilon=\mathrm{R} \ln \left(1+\frac{1}{\mathrm{C}_{\mathrm{e}}}\right)\end{array}$ & [34] & $\begin{array}{l}(7) \\
(8)\end{array}$ \\
\hline
\end{tabular}

\subsection{Kinetic Studies}

Conducting kinetic tests is very important in the processes of water and wastewater treatment due to the information obtained in this way, including the mechanism of the sorption process or the optimal time of the process. The most popular kinetic models are the pseudo-first-order model, also called the Lagergren model, and the pseudo-secondorder model, invented by Ho [35]. Additionally, you can also find the use of the Elovich and Weber-Morris models. These equations take into account the sorption capacity of the adsorbents and are presented in Table 3.

Table 3. Nonlinear kinetic equations.

\begin{tabular}{|c|c|c|c|}
\hline Kinetic Models & Equation & Reference & No. Equation \\
\hline Pseudo-first-order & $\mathrm{q}_{\mathrm{t}}=\mathrm{q}_{1}\left(1-\exp \left(-\mathrm{k}_{1} \mathrm{t}\right)\right)$ & [36] & (9) \\
\hline Pseudo-second-order & $\mathrm{q}_{\mathrm{t}}=\frac{\mathrm{t}}{\left(1 / \mathrm{k}_{2} \mathrm{q}_{2}^{2}+\left(\mathrm{t} / \mathrm{q}_{2}\right)\right.}$ & [37] & (10) \\
\hline Elovich & $\mathrm{q}_{\mathrm{t}}=\frac{1}{\beta} \ln (1+\alpha \beta \mathrm{t})$ & [38] & (11) \\
\hline Weber-Morris & $\mathrm{q}_{\mathrm{t}}=\mathrm{K}_{\mathrm{id}} \sqrt{\mathrm{t}}+\mathrm{I}$ & [39] & (12) \\
\hline
\end{tabular}

Based on the obtained results, the order of the reaction, the reaction rate constant and the optimal process time can be determined. The most effective removal of metals from a solution occurs when the adsorption process equilibrium is established. 


\section{Results and Discussion}

\subsection{Characteristic of $R A$ and $R A-S C$}

In this study, we successfully obtained the RA-SC composite using raphia fibers as a carrier and immobilized the yeast Saccharomyces cerevisiae on its surface as a new biosorbent for removing lead ions from water and wastewater. Comparison of the surface morphology of SC, RA and RA-SC was performed using SEM (Figure 1). SC surface analysis showed that SC cells are characterized by a spheroid or slightly elongated spheroidal shape with regular and smooth surfaces. The regular surface area turned out to be very large and advantageous for the adsorption process (Figure 1A). SEM micrographs showed that the RA surface is heterogeneous and porous (Figure 1B). Additionally, BET analysis showed that the specific surface area of RA had a specific surface area of $1.079 \mathrm{~m}^{2} / \mathrm{g}$, moreover, RA surface is characterized by a mesoporous structure. In Figure 1C, we can see SC cells on the surface of RA. The observed changes in morphology suggested that RA as a carrier is good support for SC cells. This confirms that the SC and RA cells were permanently attached after the immobilization process. In addition, an increase in the pore structure is observed, thanks to which ion transfer is possible, which increases the ability to remove impurities. The cell wall surface of one SC cell was not obscured by adjacent cells and thus was open to sufficient contact with lead ions, which increased the adsorption process. Figure 1D shows the changes in $\mathrm{SC}$ after the $\mathrm{Pb}$ (II) sorption process (RA-SC-Pb). In the photo, we can see that the shape of the cells has not changed much, and the presence of the removed lead ions is visible in the form of speckled particles distributed on the surface of the cells. Based on this, it can be assumed that the cell wall was the main part of the SC for $\mathrm{Pb}$ (II) adsorption. Similar observations were made by Zhang et al. in their research on the removal of heavy metal ions on yeast cells [40]. The EDX analysis of SC cells before sorption showed the presence of such elements as $\mathrm{K}, \mathrm{N}, \mathrm{O}, \mathrm{C}, \mathrm{P}$ and $\mathrm{S}$, and additionally $\mathrm{Pb}$ after the process. Moreover, the presence of $\mathrm{Pb}$ on the RA surface was observed, and therefore these morphological changes can be attributed to the interaction of $\mathrm{Pb}$ (II) with RA-SC surface functional groups, which is consistent with the results of the FT-IR spectra analysis.
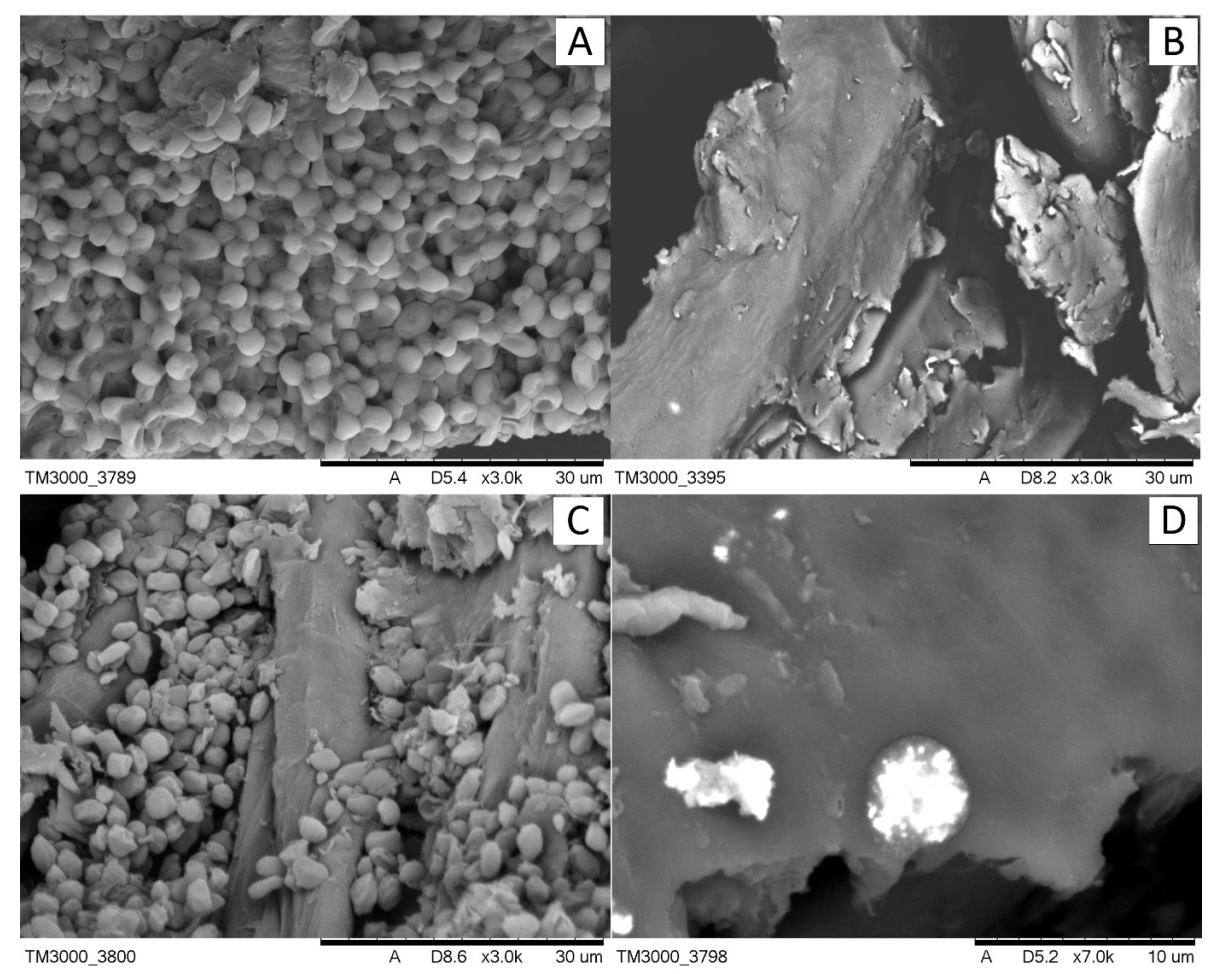

Figure 1. SEM microphotography: (A) SC, (B) RA, (C) RA-SC, (D) RA-SC-Pb. 
The performed analysis of FTIR SC, RA, RA-SC and RA-SC-Pb is shown in Figure 2. The analysis showed a difference in the chemical structure, the nature of bonds and interactions between the materials. Differences in frequency and intensity of the bands are observed, especially in the case of SC and other materials. The most intense broad band in the range of $2990-3600 \mathrm{~cm}^{-1}$ corresponds to the stretching vibrations of the hydroxyl groups $-\mathrm{OH}$ [41], in the range 2916-2922 $\mathrm{cm}^{-1}$ there are $v_{\text {asym }} \mathrm{CH}_{2}$ (a large change in intensity and a shift of the peak in RA-SC can be observed before and after sorption in relation to SC and RA) and in the range of 2848 and $2853 \mathrm{~cm}^{-1} v_{\mathrm{sym}} \mathrm{CH}_{2}$ (there is a change in the intensity of the peak in RA-SC before and after sorption against SC and RA) [42,43]; bands related to $\mathrm{C}-\mathrm{O}$ bonding, $\mathrm{C}-\mathrm{N}$ axial deformation, and primary amine bending $\mathrm{NH}_{2}$ were observed at $1637 \mathrm{~cm}^{-1}$ [44], stretching vibrations in lipid esters $(-\mathrm{C}=\mathrm{O})$ exist at the wavenumber $1734 \mathrm{~cm}^{-1}$ (shifted from $1741 \mathrm{~cm}^{-1} \mathrm{SC}$ and $1731 \mathrm{~cm}^{-1} \mathrm{RA}$ ), the strong peak at $1040-1021 \mathrm{~cm}^{-1}$ corresponds to $\mathrm{C}-\mathrm{O}$ stretching caused by glycosidic bonding, $\mathrm{OH}$ groups in sugars, or C-O-C stretching vibrations in lignin or hemicellulose, the $\delta \mathrm{C}-\mathrm{H}$ bonding of the aromatic ring, $\mathrm{S}=\mathrm{O}$ stretching, 1060-1020 $\mathrm{cm}^{-1}$ [45-47]. Moreover, the relative intensity of the $1021 \mathrm{~cm}^{-1}$ band increases after the RA-SC-Pb adsorption process compared to RA-SC. Meanwhile, the absorption peak of $-\mathrm{NH}_{2}$ stretching shifted from 1396 to $1412 \mathrm{~cm}^{-1}$, and after sorption to $1406 \mathrm{~cm}^{-1}$, indicating that the amine group was involved in coordination with $\mathrm{Pb}(\mathrm{II})$, leading to an increase in the $-\mathrm{NH}_{2}$ bond length in the SC. The $1235 \mathrm{~cm}^{-1}$ peak is responsible for $\mathrm{C}=\mathrm{O}$ vibrations [48], the anti-symmetric phosphate stretching band around $1241 \mathrm{~cm}^{-1}$ should therefore not be considered for estimation of lipid content [49]; the $\mathrm{N}-\mathrm{H}$ and $\mathrm{C}-\mathrm{N}$ vibrations of the peptide bond in different protein conformations $1590-1540 \mathrm{~cm}^{-1}$ (there is a shift of the peak maximum $\Delta \bar{v}=14 \mathrm{~cm}^{-1}$ after the $\mathrm{Pb}$ (II) sorption, indicating that nitrogen atoms are the adsorption sites for $\mathrm{Pb}(\mathrm{II})$ adsorption on $\mathrm{RA}-\mathrm{SC}$ ) [42,50]; 895-807 $\mathrm{cm}^{-1}$ represents the presence of sugars, mainly monosaccharides [51]; in the $600-400 \mathrm{~cm}^{-1}$ band, vibrations occur due to CNC deformation [52].

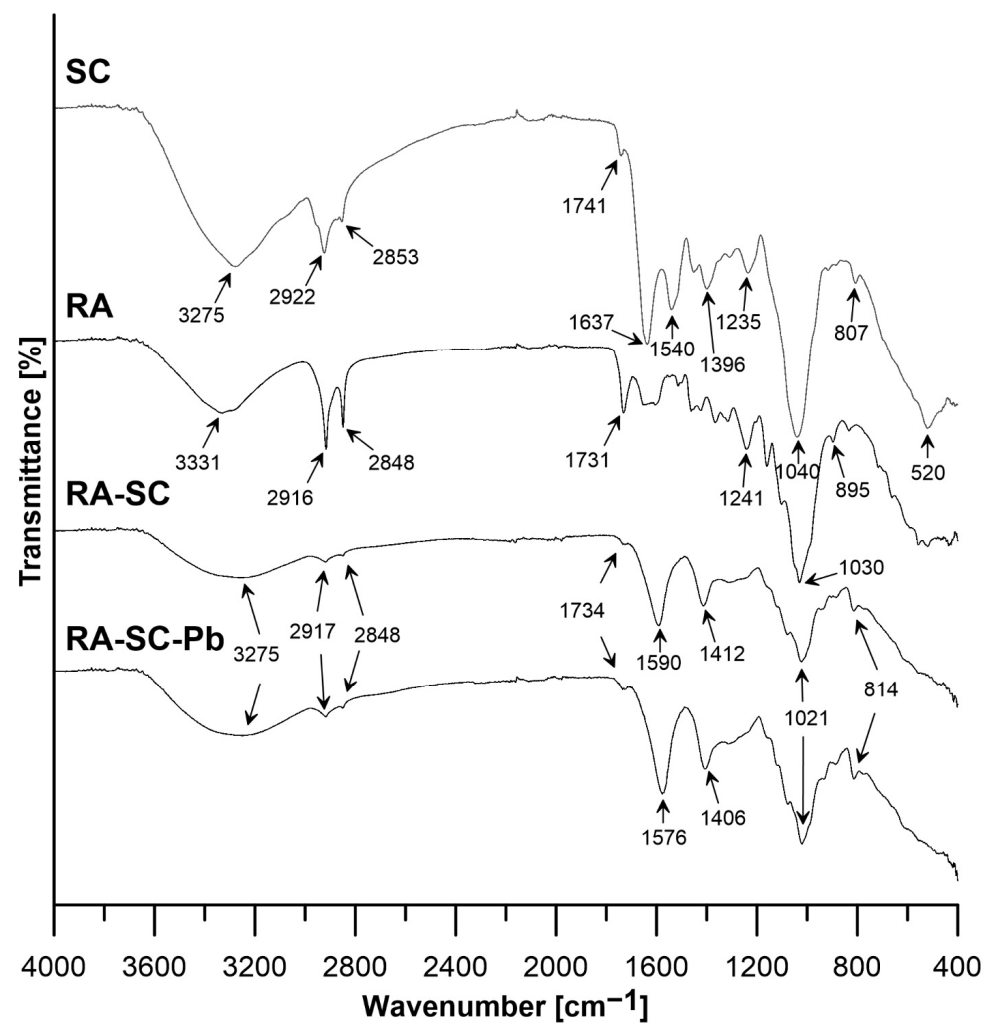

Figure 2. Results of FT-IR analysis SC, RA, RA-SC and RA-SC-Pb. 
Based on the results of the FTIR analysis, it can be concluded that the observed spectral changes after $\mathrm{Pb}$ (II) sorption on RA-SC most likely result from possible changes in the chemical structure of the composite. Thus, the described spectral differences suggest the participation of the above-mentioned functional groups in the binding of $\mathrm{Pb}$ (II) to the RA-SC surface.

\subsection{Effect of Time and Initial Concentration on Metal Ion Sorption}

The first stage of the sorption process is the determination of the time after which the equilibrium between the sorbent and the sorbate is established. Based on the experimental data, the equilibrium time was set at $30 \mathrm{~min}$. Figure 3 shows the effect of the processing time on the sorption capacity of RA (Figure 3A) and RA-SC (Figure 3B). It was observed that the lead ion sorption process on RA and RA-SC consisted mainly of two stages. In the initial stage of the process, a rapid increase in sorption capacity was observed for both materials. It could be observed that the uptake of $\mathrm{Pb}(\mathrm{II})$ ions increased significantly early in the process, which was probably due to electrostatic attraction and a large amount of free active sites. The initial increase in $\mathrm{q}_{t}$ was related to the number of available active sites capable of binding lead ions. In the initial phase, the sorbent has a large number of active centers, and the ingredients are strongly adsorbed to the active centers [53]. The highest temporary increase in sorption capacity was observed within $3 \mathrm{~min}$. For RA, the difference in $\mathrm{q}_{\mathrm{t}}$ between 3 and $1 \mathrm{~min}$ varied from $1.1 \mathrm{mg} / \mathrm{g}\left(\mathrm{C}_{0}=100 \mathrm{mg} / \mathrm{dm}^{3}\right)$ to $1.91 \mathrm{mg} / \mathrm{g}$ $\left(\mathrm{C}_{0}=500 \mathrm{mg} / \mathrm{dm}^{3}\right)$, and for RA-SC in in the range from $1.7 \mathrm{mg} / \mathrm{g}\left(\mathrm{C}_{0}=100 \mathrm{mg} / \mathrm{dm}^{3}\right)$ to $13.9 \mathrm{mg} / \mathrm{g}\left(\mathrm{C}_{0}=500 \mathrm{mg} / \mathrm{dm}^{3}\right)$. The second slower step occurred before the lead ion sorption reached equilibrium, which was a gradual adsorption step. With the time the process is carried out, the difference between $\mathrm{q}_{\mathrm{t}}$ and the following times decreases until an equilibrium is established. Additionally, it can be observed that an increase in the initial concentration of lead ions causes an increase in the value of the sorption capacity. This is due to the higher number of lead ions, which also translates into an increase in the number of collisions between them and the active centers on RA and RA-SC [54]. In addition, it can be observed that the curves of the lead ion removal process are more vertical in the case of RA-SC, which is related to its better ability to remove the studied ions. The maximum sorption capacity obtained for the removal of $\mathrm{Pb}$ (II) on RA was $16.6 \mathrm{mg} / \mathrm{g}$ and for RA-SC it was $94.8 \mathrm{mg} / \mathrm{g}$ as a function of time. Moreover, the present study showed that the maximum adsorption capacity of RA-SC was significantly higher (almost 6-fold higher) than that of RA. The difference in sorption capacity between RA and RA-SC is related to the activity of Saccharomyces cerevisiae yeast and the method of immobilization of microorganisms (the material after immobilization additionally contained calcium alginate). The difference in the initial and final sorption capacities in the materials is a direct result of their composition. The RA material is raphia fibers that have not undergone any modifications, so in the case of RA responsible for the lead ion sorption process are cellulose, hemicellulose, lignin, extracts, and many other compounds, such as lipids, starch, hydrocarbons, simple proteins and ash [55]. Organic compounds (lignin, cellulose and hemicellulose) with polyphenolic groups could bind heavy metal ions through different mechanisms [56]. The ability to remove heavy metal ions by such biosorbents (without modification) is much lower than after modification. Wu et al. in their research found that the sorption capacity in relation to $\mathrm{Pb}(\mathrm{II})$ of unmodified biosorbents was equal to: cotton-10.78 mg/g, wood sawdust- $17.03 \mathrm{mg} / \mathrm{g}$, buckwheat hull-34.06 mg/g [57]. RA-SC achieved excellent contact with the solution and lead ions by increasing the pore structure and the fact that the SC cell walls were not obstructed by adjacent cells. RA-SC achieved excellent contact with the solution and lead ions by increasing the pore structure and the fact that the SC cell walls were not obstructed by adjacent cells. According to Zhang et al., immobilization of yeast cells increased the sorption capacity by almost 60\% [40]. Other researchers in a study of lead and cadmium ion removal by EDTAD-functionalized Saccharomyces cerevisiae sorbent came to similar results. They observed that the removal of lead ions was very fast, in the first $5 \mathrm{~min}$ of the process, almost $90 \%$ of adsorption took place, and after $30 \mathrm{~min}$ it 
reached the equilibrium state $\left(\mathrm{q}_{\mathrm{e}}=83.99 \mathrm{mg} / \mathrm{g}\right)$ [6]. This type of adsorption is typical for surface adsorption behavior, the adsorption capacity of which depends on the number of available adsorption sites on the adsorbent surface [58]. The high adsorption capacity and short adsorption equilibrium time showed that the RA-SC surface has a high density of functional groups. In addition, the reason for determining the adsorption equilibrium time within 30 min may be the gradual penetration by lead ions of the outer structural layer of the yeast cell wall (due to the functional groups present therein), which was destroyed by the vacuum freeze-drying step in the RA-SC preparation processes. Figure $3 \mathrm{C}$ shows the rates of lead ion removal by RA and RA-SC. The value of $R_{e}$ decreases with the increase of the initial concentration of $\mathrm{Pb}$ ions, which is directly related to the affinity of the tested materials for $\mathrm{Pb}(\mathrm{II})$. For $\mathrm{RA}$, a change in $\mathrm{R}_{\mathrm{e}}$ was observed from $33.5 \%$ to $16.5 \%$ (a difference of $17 \mathrm{pp}$ ), with the difference between the individual concentrations of $\mathrm{C}_{0}$ decreasing by 6 pp to 1 pp, and for RA-SC, the change in $\mathrm{R}_{\mathrm{e}}$ was about $5 \mathrm{pp}$, from $\sim 98 \%$ to $\sim 93 \%$, with the $\mathrm{R}_{\mathrm{e}}$ difference between the individual concentrations of $\mathrm{C}_{0}$ being low, in the range of 1-1.9\%. This was confirmed by the fact that RA-SC has higher $\mathrm{Pb}$ (II) removal abilities than RA.
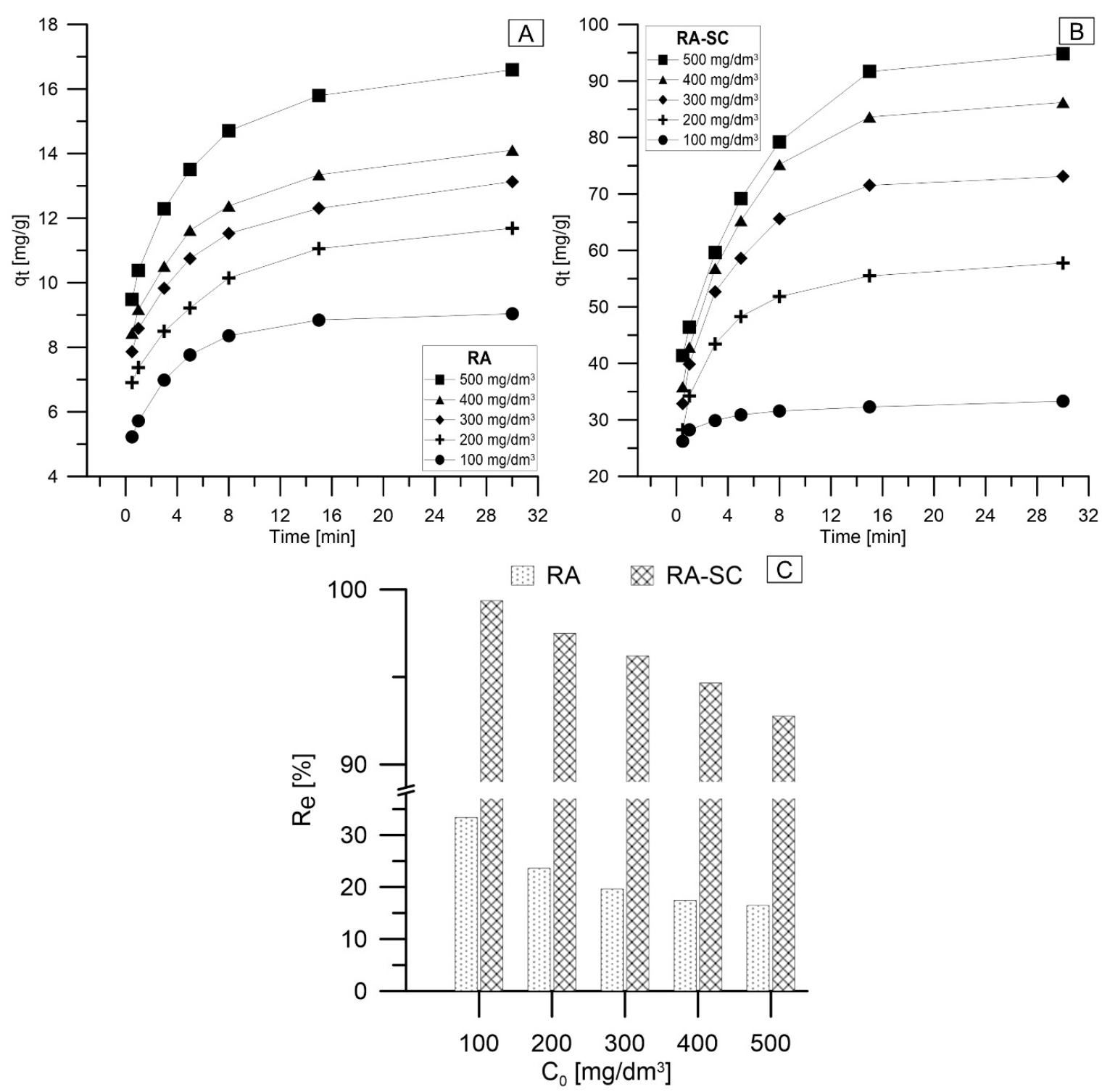

Figure 3. The sorption capacity in time depending on the initial concentration: (A) RA, (B) RA-SC, (C) the degree of metal removal from the RA and RA-SC model solutions $\left(\mathrm{T}=25^{\circ} \mathrm{C}, \mathrm{pH}=5\right)$. 


\subsection{Equilibrium Studies}

To learn the nature of the sorption process, equilibrium and kinetic studies were used. Four isotherm models were investigated in the study: Langmuir, Freundlich, Tempkin and Dubinin-Radushkevich. Figure 4 and Table 4 show the obtained results of the equilibrium tests. To select the isotherm model that best describes the process of removing Pb ions on $\mathrm{RA}$ and RA-SC, the average relative error ARE and the correlation coefficient $R^{2}$ were used. It can be observed that the type of sorbent affects the course of sorption. The Temkin model is the model that best describes the process of $\mathrm{Pb}$ (II) removal by RA and RA-SC. For RA, ARE was $1.77 \%$ and $R^{2}=0.9884$, while for RA-SC, ARE was $0.95 \%$ and $R^{2}=0.9984$. Additionally, high matches were found for the Langmuir model for RA-SC (ARE $=2.82 \%, R^{2}=0.9934$ ) and the Freundlich model for RA (ARE $=1.80 \%, R^{2}=0.9839$ ). The Temkin isotherm contains a factor that clearly takes into account the adsorbent-adsorbate interactions. It is assumed that due to these interactions and the omission of very low and very high concentration values, the heat of adsorption of all molecules in the layer would decrease linearly with the coverage [59]. The values obtained from the Temkin isotherm for RA were: $\mathrm{K}_{\mathrm{T}}=0.22 \mathrm{dm}^{3} \mathrm{~g}^{-1}$ and $\mathrm{B}=3.3 \mathrm{kJmol}^{-1}$, which indicates that adsorption of $\mathrm{Pb}$ (II) on RA takes place by physisorption. The binding energy value was $<8 \mathrm{kJmol}^{-1}$, thus physical adsorption is the mechanism involved. In the physiadsorption process, adsorbates adhere to the adsorbent through weak van der Waals interactions, and thus this process is associated with relatively low adsorption energies [60]. However, in the case of RA-SC, the obtained values were $\mathrm{K}_{\mathrm{T}}=2.3 \mathrm{dm}^{3} \mathrm{~g}^{-1}$ and $\mathrm{B}=21.7 \mathrm{kJmol}^{-1}$, which proves in this case that we are dealing with chemisorption. Based on the Freundlich isotherm for RA, the calculated parameter $1 / \mathrm{n}$ was 0.28 , which allows us to conclude that RA is a suitable sorbent for $\mathrm{Pb}(\mathrm{II})$ removal (value $1 / \mathrm{n}<1$ ) [61]. The Freundlich isotherm predicts infinite surface coverage and therefore does not predict the saturation of the material by the sorbed compound (multi-layer adsorption model). The calculated parameter $\mathrm{n}=3.57$, which is in the range of $1<\mathrm{n}<10$, indicates favourable sorption conditions [62]. Langmuir adsorption isotherm is based on the assumption that all sorption sites are equivalent and there is no dependence of the sorption sites on the occupied neighboring sites [63]. The theoretical saturation capacity of the monolayer is $109.1 \mathrm{mg} / \mathrm{g}$ (RA-SC). The fact that the experimental data fit well with the Langmuir isotherm may be due to the homogeneous distribution of active centers on the RA-SC surface, since the Langmuir equation assumes that the surface is homogeneous [64]. Similar results from their research on $\mathrm{Pb}$ (II) removal on activated carbon obtained from apricot kernels were obtained by Mouni et al. [65]. In the case of these studies, the Langmuir isotherm was the best fit of all the isotherms tested, and the calculated separation coefficient also indicated favorable sorption conditions.

Table 4. Parameters of sorption isotherms models.

\begin{tabular}{|c|c|c|c|c|c|}
\hline Isotherm Model & & & & & \\
\hline \multirow{3}{*}{ Langmuir } & & ARE [\%] & $R^{2}$ & $\mathrm{q}_{\mathrm{m}}[\mathrm{mg} / \mathrm{g}]$ & $\mathrm{K}_{\mathrm{L}}\left[\mathrm{dm}^{3} / \mathrm{mg}\right]$ \\
\hline & RA & 3.18 & 0.9583 & 17.139 & 0.0155505 \\
\hline & RA-SC & 2.82 & 0.9934 & 106.089 & 0.1985247 \\
\hline \multirow{3}{*}{ Freundlich } & & ARE [\%] & $\mathrm{R}^{2}$ & $\mathrm{~K}_{\mathrm{F}}\left(\mathrm{mg}^{1-(1 / \mathrm{n})}\left(\mathrm{dm}^{3}\right)^{1 / \mathrm{n}} \mathrm{g}^{-1}\right)$ & $1 / \mathrm{n}$ \\
\hline & RA & 1.80 & 0.9839 & 2.81066 & 0.28086 \\
\hline & RA-SC & 6.49 & 0.9705 & 30.61679 & 0.32560 \\
\hline \multirow{3}{*}{ Temkin } & & ARE [\%] & $R^{2}$ & $\mathrm{~K}_{\mathrm{T}}\left[\mathrm{dm}^{3} / \mathrm{g}\right]$ & B \\
\hline & RA & 1.77 & 0.9884 & 0.2194991 & 3.347 \\
\hline & RA-SC & 0.95 & 0.9984 & 2.2944000 & 21.711 \\
\hline \multirow{3}{*}{ D-R } & & ARE [\%] & $\mathrm{R}^{2}$ & $\mathrm{~K}_{\mathrm{ad}}\left[\mathrm{mol}^{2} / \mathrm{kJ} J^{2}\right]$ & $\mathrm{q}_{\mathrm{d}}[\mathrm{mg} / \mathrm{g}]$ \\
\hline & RA & 3.99 & 0.9353 & 0.0171906 & 16.199 \\
\hline & RA-SC & 6.36 & 0.9683 & 0.0012690 & 98.249 \\
\hline
\end{tabular}




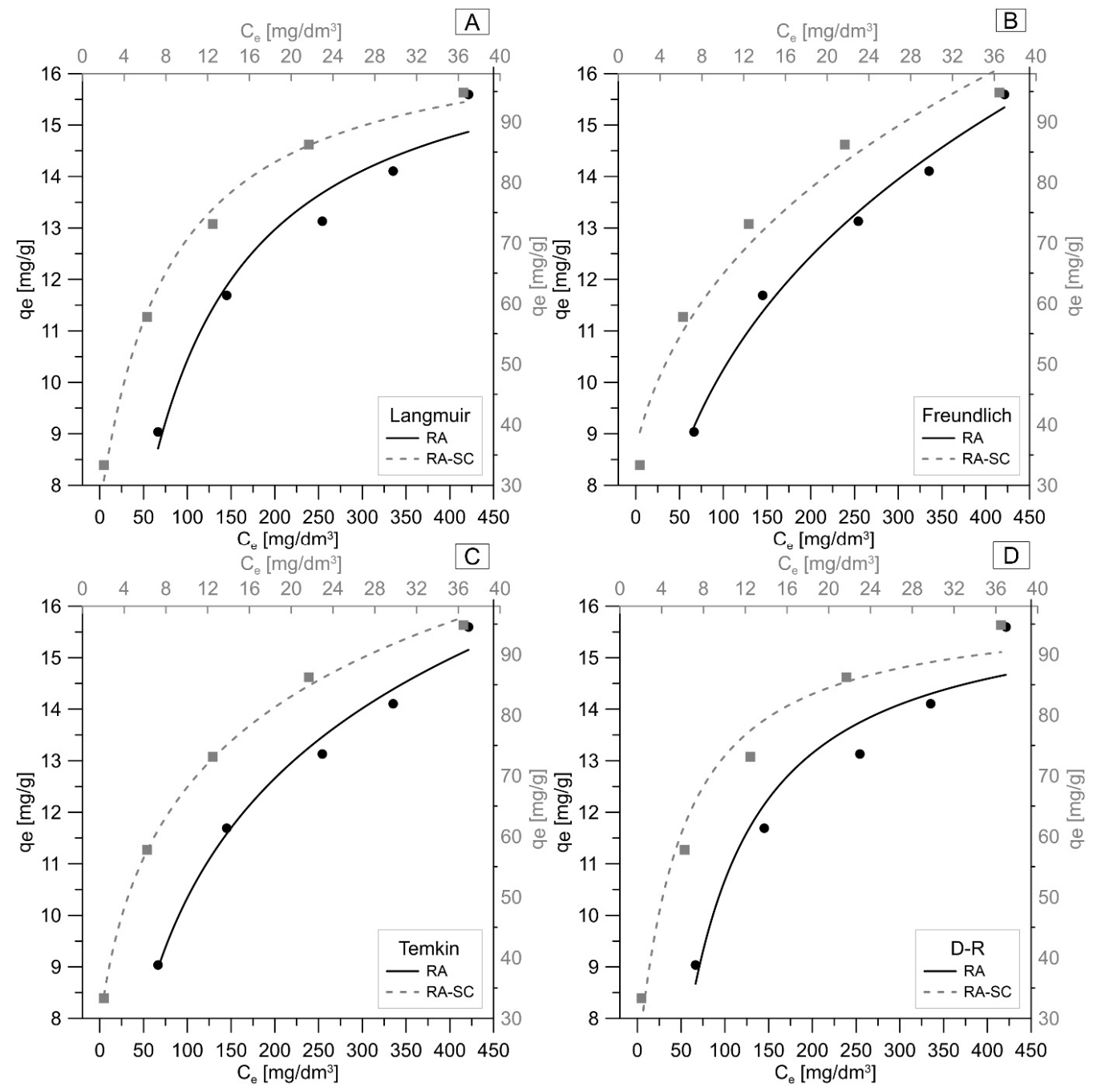

Figure 4. Graphic representation of sorption isotherms RA and RA-SC: (A) Langmuir, (B) Freundlich, (C) Temkin, (D) D-R $\left(\mathrm{T}=25^{\circ} \mathrm{C}, \mathrm{pH}=5\right)$.

\subsection{Kinetic Studies}

Many physicochemical factors can limit the speed of the sorption process. One of the main factors is the interaction between the sorbate and the sorbent surface. Both penetration into the pores and the deposition of sorbate on the sorbent surface affect the sorption rate. The obtained kinetic results presented in Figure 5 and Table 5 show that in the case of RA, the ratio of $\mathrm{q}_{\mathrm{t}}$ in $30 \mathrm{~min}$ to $\mathrm{q}_{\mathrm{t}}$ does not change during $0.5 \mathrm{~min}$ during the change of the initial concentration of $\mathrm{Pb}$ (II), which is 1.73 for $\mathrm{C}_{0}=100 \mathrm{mg} / \mathrm{dm}^{3}$ and 1.75 for $\mathrm{C}_{0}=500 \mathrm{mg} / \mathrm{dm}^{3}$. However, in the case of RA-SC, this difference is significant, and amounts to 1.27 for $C_{0}=100 \mathrm{mg} / \mathrm{dm}^{3}$ and 2.29 for $C_{0}=500 \mathrm{mg} / \mathrm{dm}^{3}$. It is related to the number of moles of $\mathrm{Pb}(\mathrm{II})$ in the solution. Initially, there is a large number of sorbate moles in the solution, which means that the filling of free active centers is associated with a lower driving force resulting from a smaller number of active collisions between $\mathrm{Pb}(\mathrm{II})$ and RA and RA-SC. On the other hand, with an increase in the initial concentration, a greater number of active collisions is observed, which translates into a greater initial $\mathrm{q}_{t}$ [54]. Additionally, it was observed that depending on the type of sorbent, the ratio of sorption capacity changes at the initial concentration of $\mathrm{Pb}(\mathrm{II})$. For $\mathrm{RA}$ this ratio is 1.84 and for RA-SC it is 2.85 , which proves that RA-SC has higher lead ion removal capacity and therefore an increase in $\mathrm{C}_{0}$ concentration translates into an increase in $\mathrm{q}_{\mathrm{e}}$. 

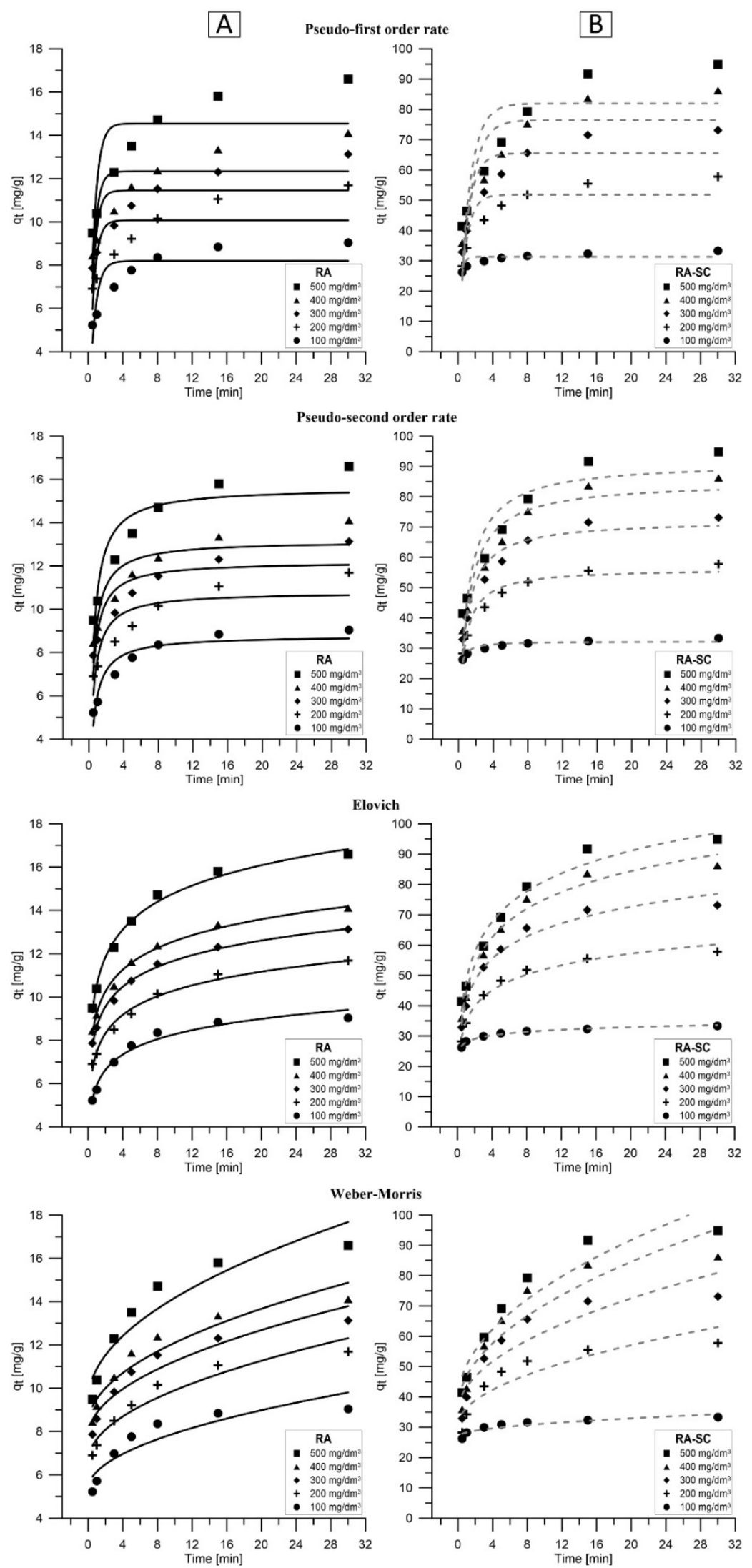

Figure 5. Graphic representation of pseudo-first-order, pseudo-second-order, Elovich and WeberMorris models for the process of ions adsorption: (A) RA, (B) RA-SC $\left(\mathrm{T}=25^{\circ} \mathrm{C}, \mathrm{pH}=5\right)$. 
Table 5. Parameters of sorption kinetic models for the sorption process $\mathrm{Pb}$ ions.

\begin{tabular}{|c|c|c|c|c|c|c|}
\hline \multirow{2}{*}{\multicolumn{2}{|c|}{ Kinetic Model }} & \multicolumn{5}{|c|}{ Lead Ion Concentration $\mathrm{C}_{0}\left[\mathrm{mg} / \mathrm{dm}^{3}\right]$} \\
\hline & & 100 & 200 & 300 & 400 & 500 \\
\hline \multicolumn{7}{|c|}{ Pseudo-first-order rate } \\
\hline \multirow{4}{*}{ RA } & $\mathrm{q}_{1}[\mathrm{mg} / \mathrm{g}]$ & 8.190 & 10.073 & 11.452 & 12.334 & 14.547 \\
\hline & $\mathrm{k}_{1}\left[\min ^{-1}\right]$ & 1.5451 & 1.7929 & 1.8558 & 1.8258 & 1.6270 \\
\hline & $\mathrm{R}^{2}$ & 0.7189 & 0.5612 & 0.6158 & 0.6137 & 0.6502 \\
\hline & ARE [\%] & 9.80 & 11.19 & 9.63 & 9.82 & 10.53 \\
\hline \multirow{4}{*}{ RA-SC } & $\mathrm{q}_{1}[\mathrm{mg} / \mathrm{g}]$ & 31.328 & 51.796 & 65.565 & 76.454 & 81.915 \\
\hline & $\mathrm{k}_{1}\left[\mathrm{~min}^{-1}\right]$ & 3.3515 & 1.2194 & 0.9935 & 0.7753 & 0.8181 \\
\hline & $\mathrm{R}^{2}$ & 0.6748 & 0.8125 & 0.8051 & 0.7740 & 0.6878 \\
\hline & ARE $[\%]$ & 3.70 & 9.02 & 10.50 & 13.25 & 14.94 \\
\hline \multicolumn{7}{|c|}{ Pseudo-second-order rate } \\
\hline \multirow{4}{*}{ RA } & $\mathrm{q}_{2}[\mathrm{mg} / \mathrm{g}]$ & 8.777 & 10.789 & 12.197 & 13.153 & 15.618 \\
\hline & $\mathrm{k}_{2}\left[\mathrm{~min}^{-1}\right]$ & 0.2534 & 0.2354 & 0.2258 & 0.2041 & 0.1465 \\
\hline & $\mathrm{R}^{2}$ & 0.9088 & 0.7963 & 0.8387 & 0.8382 & 0.8623 \\
\hline & ARE [\%] & 5.56 & 7.65 & 6.21 & 6.43 & 6.57 \\
\hline \multirow{4}{*}{ RA-SC } & $\mathrm{q}_{2}[\mathrm{mg} / \mathrm{g}]$ & 32.222 & 56.295 & 72.189 & 85.027 & 91.513 \\
\hline & $\mathrm{k}_{2}\left[\min ^{-1}\right]$ & 0.2445 & 0.0290 & 0.0176 & 0.0117 & 0.0111 \\
\hline & $\mathrm{R}^{2}$ & 0.9074 & 0.9554 & 0.9482 & 0.9270 & 0.8754 \\
\hline & ARE [\%] & 1.94 & 4.54 & 5.57 & 7.52 & 9.73 \\
\hline \multicolumn{7}{|c|}{ Elovich } \\
\hline \multirow{4}{*}{ RA } & $\beta[\mathrm{g} / \mathrm{mg}]$ & 0.9763 & 0.8080 & 0.7539 & 0.6908 & 0.5424 \\
\hline & $\alpha[\mathrm{mg} / \mathrm{g} \cdot \mathrm{min}]$ & 332.8 & 514.7 & 892.4 & 866.1 & 566.0 \\
\hline & $\mathrm{R}^{2}$ & 0.9753 & 0.9830 & 0.9948 & 0.9925 & 0.9915 \\
\hline & ARE [\%] & 2.35 & 2.21 & 1.02 & 1.32 & 1.64 \\
\hline \multirow{4}{*}{ RA-SC } & $\beta[\mathrm{g} / \mathrm{mg}]$ & 0.5966 & 0.1325 & 0.0940 & 0.0735 & 0.0685 \\
\hline & $\alpha[\mathrm{mg} / \mathrm{g} \cdot \mathrm{min}]$ & $28,433,115$ & 737.9 & 487.4 & 334.8 & 373.3 \\
\hline & $\mathrm{R}^{2}$ & 0.9825 & 0.9818 & 0.9801 & 0.9825 & 0.9772 \\
\hline & ARE [\%] & 0.94 & 2.62 & 2.74 & 3.01 & 4.18 \\
\hline \multicolumn{7}{|c|}{ Weber-Morris } \\
\hline \multirow{4}{*}{ RA } & I & 5.3411 & 6.6159 & 7.7652 & 8.3106 & 9.3924 \\
\hline & $\mathrm{K}_{\mathrm{id}}$ & 0.8144 & 1.0401 & 1.1002 & 1.1985 & 1.5125 \\
\hline & $\mathrm{R}^{2}$ & 0.8300 & 0.9353 & 0.9206 & 0.9153 & 0.8989 \\
\hline & ARE [\%] & 7.56 & 4.15 & 4.47 & 4.67 & 5.71 \\
\hline \multirow{4}{*}{ RA-SC } & I & 26.9339 & 30.4228 & 34.8629 & 35.9809 & 38.5482 \\
\hline & $\mathrm{K}_{\mathrm{id}}$ & 1.3367 & 5.9555 & 8.4153 & 10.8642 & 11.9007 \\
\hline & $\mathrm{R}^{2}$ & 0.8393 & 0.8266 & 0.8358 & 0.8714 & 0.9086 \\
\hline & ARE [\%] & 2.57 & 9.45 & 10.60 & 10.14 & 7.79 \\
\hline
\end{tabular}

Kinetic studies were carried out for four kinetic models: pseudo-first-order, pseudosecond-order, Elovich and Weber-Morris. The performed calculations allowed for the conclusion that the model that best describes the process of removing lead ions by RA and RA-SC is the Elovich model. For RA, the ARE ranged from $1.02 \%$ to $2.35 \%$ and for RA-SC 
from 0.94 to $4.18 \%$. In contrast, $\mathrm{R}^{2}$ was in the range of $0.97-0.99 \%$ for $\mathrm{RA}$ and $\sim 0.98 \%$ for RA-SC. The Elovich model assumes that there are no interactions between the adsorbed species and that the actual solid sorbent surface is energetically heterogeneous [66]. The $\alpha$ and $\beta$ coefficients appearing in the Elovich equation are related to the initial adsorption rate and the desorption coefficient. The observed value of the $\alpha$ coefficient higher than $\beta$ indicates that the dominant process is adsorption then desorption [67]. The $1 / \beta$ value reflects the number of sites available for adsorption [68]. Additionally, based on the Elovich model, it was found that with the increase of $\mathrm{C}_{0}$, the share of diffusion as the driving force of the $\mathrm{Pb}(\mathrm{II})$ removal process increases. It follows that lower concentrations of $\mathrm{C}_{0}$ favor the processes of chemical adsorption and intramolecular diffusion, and at higher concentrations, the activation energy is higher, which means that they share in chemical sorption is higher, which increases the sorption capacity [69]. The compliance of the Elovich equation with the experimental data obtained for RA (for which the information obtained in the equilibrium studies that physisorption is responsible for the $\mathrm{Pb}(\mathrm{II})$ removal process) is related to the heterogeneity of the RA structure. The heterogeneity of RA is associated with a change in the chemisorption energetics with active centers. In heterogeneous material, active centers show different activation energies for chemisorption, which is directly related to the presence of cellulose, lignin, hydroxyl groups, tannins and phenolic compounds [70,71]. The Elovich model is characterized by a good fit to the data obtained for sorption on highly inhomogeneous surfaces and shows that apart from surface adsorption, chemisorption is also the dominant phenomenon. On such a heterogeneous material, apart from surface adsorption, additionally, chemisorption, precipitation, intramolecular diffusion and ion exchange are observed, which occur simultaneously. The Elovich equation does not predict any particular mechanism, but is useful in describing adsorption on highly heterogeneous adsorbents. Similar conclusions were reached by Riahi et al. in their studies of phosphate removal on date palm fibers [72]. Additionally, it was found that the constant $\alpha$ related to the rate of chemisorption increases with the increase of the initial concentration of $\mathrm{Pb}(\mathrm{II})$, which suggests that more than one mechanism regulates the removal of the studied ions [73].

\section{Conclusions}

The conducted research allows us to state that it was possible to obtain a composite biosorbent for removing lead ions from water and sewage. The obtained composite consisting of raphia fibers as a carrier and immobilized Saccharomyces cerevisiae yeast cells was characterized by high $\mathrm{Pb}(\mathrm{II})$ removal capacity. The characterization of the biosorbent after the sorption process confirmed the presence of the tested ions on its surface. The obtained RA-SC composite had a greater affinity for $\mathrm{Pb}(\mathrm{II})$ by more than $5.7 \times$ compared to $\mathrm{RA}$ (94.8 mg/g-RA-SC $16.6 \mathrm{mg} / \mathrm{g}-\mathrm{RA})$. The equilibrium model that best describes the lead ion removal process by RA-SC and RA is the Temkin isotherm model (RA: ARE $=1.77 \%$, $\mathrm{R}^{2}=0.9884$, RA-SC: ARE $\left.=0.95 \%, \mathrm{R}^{2}=0.9984\right)$. The performed kinetic studies made it possible to state that the Elovich model best describes the process of $\mathrm{Pb}$ (II) removal by $\mathrm{RA}$ and RA-SC (ARE < 4.18\% and $\mathrm{R}^{2}>0.97$ ). Moreover, compared to chemical procedures, the RA-SC synthesis procedure is simple and inexpensive. Thus, RA-SC may be a promising candidate for the removal of lead or other heavy metal ions from water and wastewater.

Author Contributions: Conceptualization, P.S.; methodology, P.S.; investigation, P.S. and J.C.; writing—original draft preparation, P.S.; writing—review and editing, P.S. and J.C.; supervision, P.S.; Visualization, P.S. All authors have read and agreed to the published version of the manuscript.

Funding: This research received no external funding.

Institutional Review Board Statement: Not applicable.

Informed Consent Statement: Not applicable.

Data Availability Statement: Not applicable.

Conflicts of Interest: The authors declare no conflict of interest. 


\section{References}

1. Shannon, M.A.; Bohn, P.W.; Elimelech, M.; Georgiadis, J.G.; Mariñas, B.J.; Mayes, A.M. Science and technology for water purification in the coming decades. Nat. Cell Biol. 2008, 452, 301-310. [CrossRef]

2. Vörösmarty, C.J.; McIntyre, P.B.; Gessner, M.O.; Dudgeon, D.; Prusevich, A.; Green, P.; Glidden, S.; Bunn, S.E.; Sullivan, C.A.; Liermann, C.R.; et al. Global threats to human water security and river biodiversity. Nature 2010, 467, 555-561. [CrossRef] [PubMed]

3. Baniamerian, M.J.; Moradi, S.E.; Noori, A.; Salahi, H. The effect of surface modification on heavy metal ion removal from water by carbon nanoporous adsorbent. Appl. Surf. Sci. 2009, 256, 1347-1354. [CrossRef]

4. Mudhoo, A.; Garg, V.K.; Wang, S. Removal of heavy metals by biosorption. Environ. Chem. Lett. 2011, 10, 109-117. [CrossRef]

5. Martínez-Huitle, C.A.; Ferro, S. Electrochemical oxidation of organic pollutants for the wastewater treatment: Direct and indirect processes. Chem. Soc. Rev. 2006, 35, 1324-1340. [CrossRef] [PubMed]

6. Zhang, Y.; Liu, W.; Zhang, L.; Wang, M.; Zhao, M. Application of bifunctional Saccharomyces cerevisiae to remove lead(II) and cadmium(II) in aqueous solution. Appl. Surf. Sci. 2011, 257, 9809-9816. [CrossRef]

7. Montes-Hernandez, G.; Concha-Lozano, N.; Renard, F.; Quirico, E. Removal of oxyanions from synthetic wastewater via carbonation process of calcium hydroxide: Applied and fundamental aspects. J. Hazard. Mater. 2009, 166, 788-795. [CrossRef]

8. Chong, M.N.; Jin, B.; Chow, C.W.K.; Saint, C. Recent developments in photocatalytic water treatment technology: A review. Water Res. 2010, 44, 2997-3027. [CrossRef] [PubMed]

9. Ali, I. New generation adsorbents for water treatment. Chem. Rev. 2012, 112, 5073-5091. [CrossRef] [PubMed]

10. Gao, Q.; Xu, J.; Bu, X.H. Recent advances about metal-organic frameworks in the removal of pollutants from wastewater. Coord. Chem. Rev. 2019, 378, 17-31. [CrossRef]

11. Farooq, U.; Kozinski, J.A.; Khan, M.A.; Athar, M. Biosorption of heavy metal ions using wheat based biosorbents-A review of the recent literature. Bioresour. Technol. 2010, 101, 5043-5053. [CrossRef] [PubMed]

12. Yu, J.; Tong, M.; Sun, X.; Li, B. Cystine-modified biomass for Cd(II) and Pb(II) biosorption. J. Hazard. Mater. 2007, 143, 277-284 [CrossRef]

13. Yin, K.; Wang, Q.; Lv, M.; Chen, L. Microorganism remediation strategies towards heavy metals. Chem. Eng. J. 2019, 360, 1553-1563. [CrossRef]

14. Martins, S.C.S.; Martins, C.M.; Fiúza, L.M.C.G.; Santaella, S.T. Immobilization of microbial cells: A promising tool for treatment of toxic pollutants in industrial wastewater. Afr. J. Biotechnol. 2016, 12, 4473. [CrossRef]

15. Kanamarlapudi, S.L.R.K.; KumarChintalpudi, V.; Muddada, S. Application of Biosorption for Removal of Heavy Metals from Wastewater. Biosorption 2018, 69-116. [CrossRef]

16. Dzionek, A.; Wojcieszyńska, D.; Guzik, U. Natural carriers in bioremediation: A review. Electron. J. Biotechnol. 2016, 23, 28-36. [CrossRef]

17. Chwastowski, J.; Staroń, P. Influence of Saccharomyces cerevisiae yeast cells immobilized on Cocos nucifera fibers for the adsorption of $\mathrm{Pb}$ (II) ions. Colloids Surf. A Physicochem. Eng. Asp. 2021, 632, 127735. [CrossRef]

18. Sarioglu, O.F.; Celebioglu, A.; Tekinay, T.; Uyar, T. Bacteria-immobilized electrospun fibrous polymeric webs for hexavalent chromium remediation in water. Int. J. Environ. Sci. Technol. 2016, 13, 2057-2066. [CrossRef]

19. Khattar, J.I.S.; Sarma, T.A.; Singh, D.P. Removal of chromium ions by agar immobilized cells of the cyanobacterium Anacystis nidulans in a continuous flow bioreactor. Enzyme Microb. Technol. 1999, 25, 564-568. [CrossRef]

20. Liu, J.; Morales-Narváez, E.; Vicent, T.; Merkoçi, A.; Zhong, G.H. Microorganism-decorated nanocellulose for efficient diuron removal. Chem. Eng. J. 2018, 354, 1083-1091. [CrossRef]

21. Ahmad, A.; Singh, A.P.; Khan, N.; Chowdhary, P.; Giri, B.S.; Varjani, S.; Chaturvedi, P. Bio-composite of Fe-sludge biochar immobilized with Bacillus Sp. in packed column for bio-adsorption of Methylene blue in a hybrid treatment system: Isotherm and kinetic evaluation. Environ. Technol. Innov. 2021, 23, 101734. [CrossRef]

22. Staroń, P.; Sorys, P.; Chwastowski, J. Equilibrium and Kinetic Study of Ammonium Sorption by Raphia farinifera. Water. Air. Soil Pollut. 2019, 230. [CrossRef]

23. Staroń, P.; Chwastowski, J.; Banach, M. Sorption behavior of methylene blue from aqueous solution by raphia fibers. Int. J. Environ. Sci. Technol. 2019, 16. [CrossRef]

24. Ofomaja, A.E.; Ho, Y.S. Effect of pH on cadmium biosorption by coconut copra meal. J. Hazard. Mater. 2007, 139, 356-362. [CrossRef]

25. Marques, B.S.; Frantz, T.S.; Sant'Anna Cadaval Junior, T.R.; de Almeida Pinto, L.A.; Dotto, G.L. Adsorption of a textile dye onto piaçava fibers: Kinetic, equilibrium, thermodynamics, and application in simulated effluents. Environ. Sci. Pollut. Res. 2019, 26, 28584-28592. [CrossRef]

26. Marques, J.L.; Lütke, S.F.; Frantz, T.S.; Espinelli, J.B.S.; Carapelli, R.; Pinto, L.A.A.; Cadaval, T.R.S. Removal of Al (III) and Fe (III) from binary system and industrial effluent using chitosan films. Int. J. Biol. Macromol. 2018, 120, 1667-1673. [CrossRef] [PubMed]

27. Rothschild, L.J.; Mancinelli, R.L. Life in extreme environments. Nature 2001, 409, 1092-1101. [CrossRef]

28. El-Sayed, M.T. Removal of lead(II) by Saccharomyces cerevisiae AUMC 3875. Ann. Microbiol. 2013, 63, 1459-1470. [CrossRef]

29. Say, R.; Denizli, A.; Yakup Arica, M. Biosorption of cadmium(II), lead(II) and copper(II) with the filamentous fungus Phanerochaete chrysosporium. Bioresour. Technol. 2001, 76, 67-70. [CrossRef] 
30. Lima, É.C.; Adebayo, M.A.; Machado, F.M. Kinetic and Equilibrium Models of Adsorption. Carbon Nanostructures 2015, 0, 33-69. [CrossRef]

31. Wu, F.C.; Tseng, R.L.; Juang, R.S. A review and experimental verification of using chitosan and its derivatives as adsorbents for selected heavy metals. J. Environ. Manag. 2010, 91, 798-806. [CrossRef]

32. Baláž, P.; Aláčová, A.; Briančin, J. Sensitivity of Freundlich equation constant $1 / \mathrm{n}$ for zinc sorption on changes induced in calcite by mechanical activation. Chem. Eng. J. 2005, 114, 115-121. [CrossRef]

33. Mousa, S.M.; Ammar, N.S.; Ibrahim, H.A. Removal of lead ions using hydroxyapatite nano-material prepared from phosphogypsum waste. J. Saudi Chem. Soc. 2016, 20, 357-365. [CrossRef]

34. Dada, A.O.; Olalekan, A.P.; Olatunya, A.M.; Dada, O. Langmuir, Freundlich, Temkin and Dubinin-Radushkevich Isotherms Studies of Equilibrium Sorption of $\mathrm{Zn}^{2+}$ Unto Phosphoric Acid Modified Rice Husk. IOSR J. Appl. Chem. 2012, 3, 38-45. [CrossRef]

35. Ho, Y.S.; McKay, G. Pseudo-second order model for sorption processes. Process Biochem. 1999, 34, 451-465. [CrossRef]

36. Cheung, C.W.; Porter, J.F.; McKay, G. Sorption kinetics for the removal of copper and zinc from effluents using bone char. Sep. Purif. Technol. 2000, 19, 55-64. [CrossRef]

37. Kumar, K.V. Linear and non-linear regression analysis for the sorption kinetics of methylene blue onto activated carbon. J. Hazard. Mater. 2006, 137, 1538-1544. [CrossRef]

38. López-Luna, J.; Ramírez-Montes, L.E.; Martinez-Vargas, S.; Martínez, A.I.; Mijangos-Ricardez, O.F.; González-Chávez, M.D.C.A.; Carrillo-González, R.; Solís-Domínguez, F.A.; del Carmen Cuevas-Díaz, M.; Vázquez-Hipólito, V. Linear and nonlinear kinetic and isotherm adsorption models for arsenic removal by manganese ferrite nanoparticles. SN Appl. Sci. 2019, 1, 1-19. [CrossRef]

39. Svilović, S.; Rušić, D.; Bašić, A. Investigations of different kinetic models of copper ions sorption on zeolite 13X. Desalination 2010, 259, 71-75. [CrossRef]

40. Zhang, Y.; Fan, C.; Meng, Q.; Diao, Z.; Dong, L.; Peng, X.; Ma, S.; Zhou, Q. Biosorption of Pb ${ }^{2+}$ by Saccharomyces Cerevisiae in Static and Dynamic Adsorption Tests. Bull. Environ. Contam. Toxicol. 2009, 83, 708-712. [CrossRef] [PubMed]

41. Evora, M.C.; Gonçalez, O.L.; Dutra, R.C.L.; Diniz, M.F.; Wiebeck, H.; de Andrade e Silva, L.G. Comparação de Técnicas FTIR de Transmissão, Reflexão e Fotoacústica na Análise de Poliamida-6, Reciclada e Irradiada. Polímeros 2002, 12, 60-68. [CrossRef]

42. Cavagna, M.; Dell'Anna, R.; Monti, F.; Rossi, F.; Torriani, S. Use of ATR-FTIR Microspectroscopy to Monitor Autolysis of Saccharomyces cerevisiae Cells in a Base Wine. J. Agric. Food Chem. 2009, 58, 39-45. [CrossRef] [PubMed]

43. Bhaduri, D.; Saha, A.; Desai, D.; Meena, H.N. Restoration of carbon and microbial activity in salt-induced soil by application of peanut shell biochar during short-term incubation study. Chemosphere 2016, 148, 86-98. [CrossRef] [PubMed]

44. Mitter, E.K.; Corso, C.R. FT-IR analysis of acid black dye biodegradation using saccharomyces cerevisiae immobilized with treated sugarcane bagasse. Water. Air. Soil Pollut. 2013, 224, 1-9. [CrossRef]

45. Wahab, M.A.; Boubakri, H.; Jellali, S.; Jedidi, N. Characterization of ammonium retention processes onto Cactus leaves fibers using FTIR, EDX and SEM analysis. J. Hazard. Mater. 2012, 241-242, 101-109. [CrossRef] [PubMed]

46. Abbas, O.; Rebufa, C.; Dupuy, N.; Kister, J. FTIR-Multivariate curve resolution monitoring of photo-Fenton degradation of phenolic aqueous solutions: Comparison with HPLC as a reference method. Talanta 2008, 77, 200-209. [CrossRef] [PubMed]

47. Cherdoud-Chihani, A.; Mouzali, M.; Abadie, M.J.M. Study of crosslinking acid copolymer/DGEBA systems by FTIR. J. Appl. Polym. Sci. 2003, 87, 2033-2051. [CrossRef]

48. El-Kabbany, F.; Hassan, T.S.; Hafez, M. Infrared spectroscopic anaylsis of polymorphism in diphenyl carbazide. Sci. Pap. Univ. Pardubice. Ser. A Fac. Chem. Technol. 2010, 16, 57-73.

49. Pistorius, A.M.A.; DeGrip, W.J.; Egorova-Zachernyuk, T.A. Monitoring of biomass composition from microbiological sources by means of FT-IR spectroscopy. Biotechnol. Bioeng. 2009, 103, 123-129. [CrossRef] [PubMed]

50. Chen, Y.; Wang, J. The characteristics and mechanism of Co(II) removal from aqueous solution by a novel xanthate-modified magnetic chitosan. Nucl. Eng. Des. 2012, 242, 452-457. [CrossRef]

51. Sathya, D.J.H.; Turakhia, A.M.; Kumar, M.A.; Balaji, N.; Selvanaveen, S.; Vinodhini, G.; Seenuvasan, M. Bioethanol from saccharificed lignocellulosic rich Aloe vera rinds using Saccharomyces cerevisiae MTCC 4779. Energy Sources Part A Recovery Util. Environ. Eff. 2017, 39, 1347-1352. [CrossRef]

52. Gunasekaran, S.; Natarajan, R.K.; Renganayaki, V.; Natarajan, S. Vibrational spectra and thermodynamic analysis of metformin. Indian J. Pure Appl. Phys. 2006, 44, 495-500.

53. Da Luz, A.D.; de Souza, S.M.D.A.G.U.; da Luz, C.; de Mello, J.M.M.; de Souza, A.A.U. Analysis of Competition between Multicomponent BTX Compounds for the Active Site of Adsorption in a Fixed-Bed Column. Ind. Eng. Chem. Res. 2013, 52, 16911-16921. [CrossRef]

54. Al-Rub, F.A.A.; El-Naas, M.; Benyahia, F.; Ashour, I. Biosorption of nickel on blank alginate beads, free and immobilized algal cells. Process Biochem. 2004, 39, 1767-1773. [CrossRef]

55. Malik, D.S.; Jain, C.K.; Yadav, A.K. Removal of heavy metals from emerging cellulosic low-cost adsorbents: A review. Appl. Water Sci. 2017, 7, 2113-2136. [CrossRef]

56. Ngah, W.S.; Hanafiah, M.A.K.M. Removal of heavy metal ions from wastewater by chemically modified plant wastes as adsorbents: A review. Bioresour. Technol. 2008, 99, 3935-3948. [CrossRef]

57. Wu, Z.; Cheng, Z.; Ma, W. Adsorption of $\mathrm{Pb}(\mathrm{II})$ from glucose solution on thiol-functionalized cellulosic biomass. Bioresour. Technol. 2012, 104, 807-809. [CrossRef] 
58. Pereira, F.V.; Gurgel, L.V.A.; Gil, L.F. Removal of $\mathrm{Zn}^{2+}$ from aqueous single metal solutions and electroplating wastewater with wood sawdust and sugarcane bagasse modified with EDTA dianhydride (EDTAD). J. Hazard. Mater. 2010, 176, 856-863. [CrossRef] [PubMed]

59. Abdelnaeim, M.Y.; El Sherif, I.Y.; Attia, A.A.; Fathy, N.A.; El-Shahat, M.F. Impact of chemical activation on the adsorption performance of common reed towards Cu(II) and Cd(II). Int. J. Miner. Process. 2016, 157, 80-88. [CrossRef]

60. Araújo, C.S.T.; Almeida, I.L.S.; Rezende, H.C.; Marcionilio, S.M.L.O.; Léon, J.J.L.; de Matos, T.N. Elucidation of mechanism involved in adsorption of $\mathrm{Pb}(\mathrm{II})$ onto lobeira fruit (Solanum lycocarpum) using Langmuir, Freundlich and Temkin isotherms. Microchem. J. 2018, 137, 348-354. [CrossRef]

61. Mu, T.-H.; Sun, H.-N. Sweet Potato Leaf Polyphenols: Preparation, Individual Phenolic Compound Composition and Antioxidant Activity. In Polyphenols in Plants, 2nd ed.; Watson, R.R., Ed.; Academic Press: London, UK, 2019; pp. 365-380.

62. Erdem, E.; Karapinar, N.; Donat, R. The removal of heavy metal cations by natural zeolites. J. Colloid Interface Sci. 2004, 280, 309-314. [CrossRef] [PubMed]

63. Özacar, M.; Şengil, I.A.; Türkmenler, H. Equilibrium and kinetic data, and adsorption mechanism for adsorption of lead onto valonia tannin resin. Chem. Eng. J. 2008, 143, 32-42. [CrossRef]

64. Özacar, M.; Şengil, I.A. Adsorption of metal complex dyes from aqueous solutions by pine sawdust. Bioresour. Technol. 2005, 96, 791-795. [CrossRef] [PubMed]

65. Mouni, L.; Merabet, D.; Bouzaza, A.; Belkhiri, L. Adsorption of Pb(II) from aqueous solutions using activated carbon developed from Apricot stone. Desalination 2011, 276, 148-153. [CrossRef]

66. Akinhanmi, F.T.; Adeogun, A.I.; Adegbuyi, A. Removal of $\mathrm{Cu} 2+$ from aqueous solution by adsorption onto quail eggshell: Kinetic and isothermal studies. J. Environ. Biotechnol. Res. 2016, 5, 1-9.

67. Khan, T.A.; Chaudhry, S.A.; Ali, I. Equilibrium uptake, isotherm and kinetic studies of Cd(II) adsorption onto iron oxide activated red mud from aqueous solution. J. Mol. Liq. 2015, 202, 165-175. [CrossRef]

68. Ahmad, M.A.; Puad, N.A.A.; Bello, O.S. Kinetic, equilibrium and thermodynamic studies of synthetic dye removal using pomegranate peel activated carbon prepared by microwave-induced KOH activation. Water Resour. Ind. 2014, 6, 18-35. [CrossRef]

69. Huang, Z.; Liu, S.; Zhang, B.; Xu, L.; Hu, X. Equilibrium and kinetics studies on the absorption of Cu(II) from the aqueous phase using a $\beta$-cyclodextrin-based adsorbent. Carbohydr. Polym. 2012, 88, 609-617. [CrossRef]

70. Özacar, M.; Şengil, I.A. A kinetic study of metal complex dye sorption onto pine sawdust. Process Biochem. 2005, 40, 565-572. [CrossRef]

71. Örnek, A.; Özacar, M.; Şengil, I.A. Adsorption of lead onto formaldehyde or sulphuric acid treated acorn waste: Equilibrium and kinetic studies. Biochem. Eng. J. 2007, 37, 192-200. [CrossRef]

72. Riahi, K.; Chaabane, S.; Thayer, B. Ben A kinetic modeling study of phosphate adsorption onto Phoenix dactylifera L. date palm fibers in batch mode. J. Saudi Chem. Soc. 2017, 21, S143-S152. [CrossRef]

73. Inyinbor, A.A.; Adekola, F.A.; Olatunji, G.A. Kinetics, isotherms and thermodynamic modeling of liquid phase adsorption of Rhodamine B dye onto Raphia hookerie fruit epicarp. Water Resour. Ind. 2016, 15, 14-27. [CrossRef] 